\title{
The Effect of Local Wisdom-Based ELSII Learning Model on the Problem Solving and Communication Skills of Pre-Service Islamic Teachers
}

\author{
Adi Fadli \\ Assoc. Prof., Department of Islamic Education, Graduate School of Universitas Islam \\ Negeri Mataram, Nusa Tenggara Barat, Indonesia, adi.fadli@ uinmataram.ac.id \\ Irwanto \\ Dr., Department of Educational Sciences, Graduate School of Yogyakarta State \\ University, Yogyakarta, Indonesia, dr_irwanto@yahoo.com
}

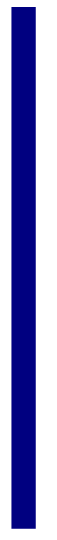

\begin{abstract}
Students' inadequate 21 st century skills are the outcome of teacher-centered learning activities. Previous studies have shown that collaborative inquiry learning improved their generic skills. This experimental research investigated the effect of Local Wisdom-Based ELSII Learning Model (LWB-ELSII) on students' problemsolving skills (PSS) and their communication skills (CS). Cluster random sampling was carried to select 56 preservice Islamic teachers at Islamic State University of Mataram as samples. The PSS Essay Test (PSET) and the Communication Skills Test (CST) were employed. The data were analyzed using Mann-Whitney U test and Spearman's rho correlation at significance level of .05. The results showed that: 1) there were significant differences in the PSS and CS between the experimental and control groups in favour of experimental group students, and 2) there was a positive and significant correlation between the two dependent variables. It is recommended that lecturers apply LWB-ELSII as an alternative solution in improving students' performance.
\end{abstract}

Keywords: ELSII learning model, local wisdom, problem solving skills, communication skills, preservice Islamic teachers

\section{INTRODUCTION}

Advancement of technology and information marked the new direction of education, emphasizing on the mastery of $21^{\text {st }}$ century skills for both students and teachers. Universities are expected to produce graduates with adequate soft skills to face the global competition. The Partnership for $21^{\text {st }}$ Century Skills [P21] (2002) identifies six key elements for fostering $21^{\text {st }}$ century learning; emphasize core subjects, emphasize learning skills, use $21^{\text {st }}$ century tools to develop learning skills, teach and learn in a $21^{\text {st }}$ century context, teach and learn 21 st century content, and use $21^{\text {st }}$ century assessments

Citation: Fadli, A., \& Irwanto. (2020). The Effect of Local Wisdom-Based ELSII Learning Model on the Problem Solving and Communication Skills of Pre-Service Islamic Teachers. International Journal of Instruction, 13(1), 731-746. https://doi.org/10.29333/iji.2020.13147a 
that measure $21^{\text {st }}$ century skills. Some learning skills are highly needed in addressing global issues including collaboration, critical thinking, creativity, problem solving and communication (P21, 2019; Sanabria \& Jesus, 2017; Trilling, \& Fadel, 2009; Irwanto, Rohaeti, \& Prodjosantoso, 2018; Irwanto et al., 2019).

Problem solving skills refer to the essential skill that should be emphasized in $21^{\text {st }}$ century learning. Problems will arise if gaps occur between the reality and expectation (Dewi, Poedjiastuti, \& Prahami, 2017). Therefore, students need problem solving skills to overcome such unstructured problems. Problem solving skills are defined as the capability to identify, plan, evaluate and find solutions in determining new answers (Erozkan, 2013; Goffin \& Tull, 1985; Santrock, 2011; Çaliskan, Selçuk, \& Erol, 2010). Dewey stated that problem solving involves several steps including identification of problems, formulation of hypothesis, hypothesis testing, and finding the most appropriate alternative solution (Moreno, 2010). Practically, students' problem solving skills strongly influence their capability in constructing their knowledge and relating one concept to others (Shih \& Singh, 2013). Constructivism in learning can be presented in meaningful learning that is based on students' experience (Moreno, 2010). Unfortunately, most of teaching and learning activities done nowadays are rather teacher-centered with major focus on mastery of certain concept (Ismiani, Syukri \& Wahyudiati, 2017; Zeidan \& Jayosi, 2015). This condition indicates the need to shift teacher-oriented learning to student-centered one and the need to improve students' intellectual capability in tertiary level.

It is truly important that university students develop their problem solving skills in order to face the work competition in the era of globalization. Research have been carried out by Aydogdu, Guven and Aka (2012), Irwanto, Saputro, Rohaeti and Prodjosantoso (2018), Seyhan (2015) and Temel (2015), which results showed that the teaching and evaluation of problem solving skills determine students' success at school and at work. In addition, problem solving skills also strongly affect students' success in life (Beyazsacli, 2016; D'Zurilla \& Chang, 1995; D'Zurilla \& Nezu, 1990; 2007). As a response to the challenges in career, higher education institutions should equip students with proper problem solving, collaborative and communication skills. Furthermore, Su (2016) confirmed that the lack in problem solving development inhibits the learning process that is expected to build coherent concept. Thus, transformation of learning practices in universities should be oriented to develop transferrable skills in order to prepare graduates with high readiness for global challenges.

Besides problem solving, communication skills are also the part of $21^{\text {st }}$ century skills that should be developed through learning process in universities. Communication is defined as a process of information exchange from informant either in verbal or nonverbal manners to receiver (Iksan et al., 2011). Communication skills consist of verbal, non-verbal and social communication skills (Bailey, 2005; Cross \& Smalldridge, 2011; Iksan et al., 2011; Khachatryan \& Karst, 2017; Mercer-Mapstone \& Matthews, 2015). Communication skills are also the element of generic skills that are important to be mastered by university students in their academic and non-academic life. Furthermore, 
communication skills determine student success in their future careers (Ihmeideh, AlOmari, \& Al-Dababneh, 2010).

Previous research indicated that communication skills are influenced by the interaction with surrounding environment and teacher-student interaction. Supportively, Adler and Rodman (2006) reported that communication skills are affected by interaction with the environment and it can be learned through learning process (Kayi, 2006). Communication skills development can be carried out based on the social constructivism learning theory (Vygotsky, 1978) by maintaining teacher-student interaction that constructs students' knowledge (Santrock, 2011; Arends, 2012) and through learning process that occurs in different cultural contexts (Penbek, Yurdakul, \& Cerit, 2012). However, several research also show that the lack of communication skills and weak learning autonomy are caused by teacher-centered learning (Asrori, 2013; Aziz, 2011; Irwanto, Rohaeti, \& Prodjosantoso, 2018; Lonto, 2016; Sadia, 2013; Wahyudiati, 2016). Therefore, the development of university students' communication skills can be administered through culture-based collaborative learning.

Local Wisdom-Based ELSII Learning (LWB-ELSII) is a collaborative learning model that is designed to improve students' transferable skills. This learning model collaborates inquiry learning and process-oriented guided-inquiry learning (POGIL) and it involves the potentials of local wisdom in learning process (Dewi, Poedjiastuti, \& Parhani, 2017). The model also opens up the chances for students to achive their learning objectives through learning processes that involve the cultural values in their surrounding environment. The implementation of LWB-ELSII will not only foster students' $21^{\text {st }}$ century skills, but it also preserves the local culture values that characterize certain nation (Dewi, Poedjiastuti, \& Parhani, 2017). Local wisdom includes local content, local intelligence, local resources, system of values, social system and local customs (Wagiran, 2011). Integration of local wisdom into teaching and learning process is considered necessary to repress the moral and spiritual crisis which appear as the negative impacts of the globalization era (Suyitno, 2012; Asmani, 2012).

Evidences obtained in previous research also show that LWB-ELSII has been effective in improving students' problem solving and communication skills. The model was developed from inquiry learning that is expected to foster students' problem solving and communication skills (Dewi, Poedjiastuti, \& Prahani, 2017). The finding is relevant with results of research conducted by Duran (2014), Trilling and Fadel (2009) and Tatar (2006) who reported that inquiry learning has been able to develop students' problem solving and communication skills. In addition, several research have proven that the implementation of POGIL successfully enhanced students' higher order thinking skills which include problem solving skills (Villagonzalo, 2014; Irwanto, Saputro, Rohaeti, \& Prodjosantoso, 2018). Similarly, learning models that engage local culture as learning resources are also associated with significant improvement in students' cognitive and generic skills (Sochima, 2013).

Based on those arguments, we believed that the implementation of LWB-ELSII would enhance the problem solving and communication skills of preservice Islamic teachers. This research was administered to explore significant differences in problem solving and 
communication skills between students who were taught using local wisdom-based learning and those who were taught using traditional method. The main research questions are:

a. Are there significant differences in pretest-postest problem solving skills scores between experimental and control group students?

b. Are there significant differences in pretest-postest communication skills scores between experimental and control group students?

\section{METHOD}

\section{Research Design}

In this research, a quasi-experimental design in the form of pretest-posttest control group was employed (see Table 1). The pretest-posttest design was used to compare the students' performance in the experimental and control groups (Creswell, 2008). There were two dependent variables in this research (i.e., problem solving and communication skills). This research was done in 12 weeks by one lecturer to avoid instructor biases. Further, pretest and posttest were given to both experimental group (Local WisdomBased ELSII Learning) and control group (traditional lecture) to determine which model gave the most significant effect to the dependent variables.

Table 1

Nonequivalent Pre- and Post-test Control Group Design

\begin{tabular}{llll}
\hline Group & Pretest & Treatment & Posttest \\
\hline Experimental & $\mathrm{O}_{1}$ & LWB-ELSII & $\mathrm{O}_{2}$ \\
Control & $\mathrm{O}_{1}$ & Traditional lecture & $\mathrm{O}_{2}$ \\
\hline
\end{tabular}

\section{Samples}

There were 56 second semester preservice Islamic teachers ( 33 female teachers, 23 male teachers) in the Faculty of Tarbiyah and Teachers Training, Islamic State University of Mataram of 2018/2019 academic year who participated as the samples in this research. The control group consisted of 28 students (12 males, 16 females), while the experimental groups consisted of 28 students (11 males and 17 females). The stipulation of experimental and control groups was done using cluster random sampling technique. The characteristics of both groups were made equal, in which participants' age ranged between $18-21$ years old and an average age of 19 .

\section{Data Collection Tools}

The Problem Solving Essay Test (PSET) consisting of 4 items was used to measure students' problem solving skills. The PSET instrument measured 4 indicators adapted from Polya (1957); understand the problem, devise a plan, carry out the plan, and look back. In addition, the Communication Skills Test (CST) adapted from Iksan et al (2013) was used to measure 3 indicators; verbal, written, and social communication skills. Both instruments had been facing validated by 4 experts in instructional instrument from Islamic State University of Mataram before they were applied. The Cronbach's alpha coefficient of PSET was .86 , and .87 for the CST, which have met the minimum 
acceptance limit of .70 (Hair, Black, Babin, \& Anderson, 2010), indicating that both instruments were reliable.

\section{Procedure}

Letter of permit had been given by the Dean of Faculty of Tarbiyah and Teachers Training, Islamic State University of Mataram, West Nusa Tenggara, Indonesia before this research was administered. This research was conducted in 3 months (November 2018 to January 2019). The data were obtained using PSET and CST which were used in pretest and posttest. During the experiments, experimental group was taught using local wisdom-based ELSII learning model, while the control group was taught using traditional learning method. In the experimental group, students identify and solve problems related to local wisdom. Furthermore, they reconstruct findings through assimilation of local wisdom, and then communicate and evaluate findings. Classroom learning was conducted once a week for 120 minutes for each group. The syntax of the local wisdom-based ELSII learning model applied in this research was adapted from Dewi, Poedjiastuti, dan Parhani (2017) as presented in Figure 1.

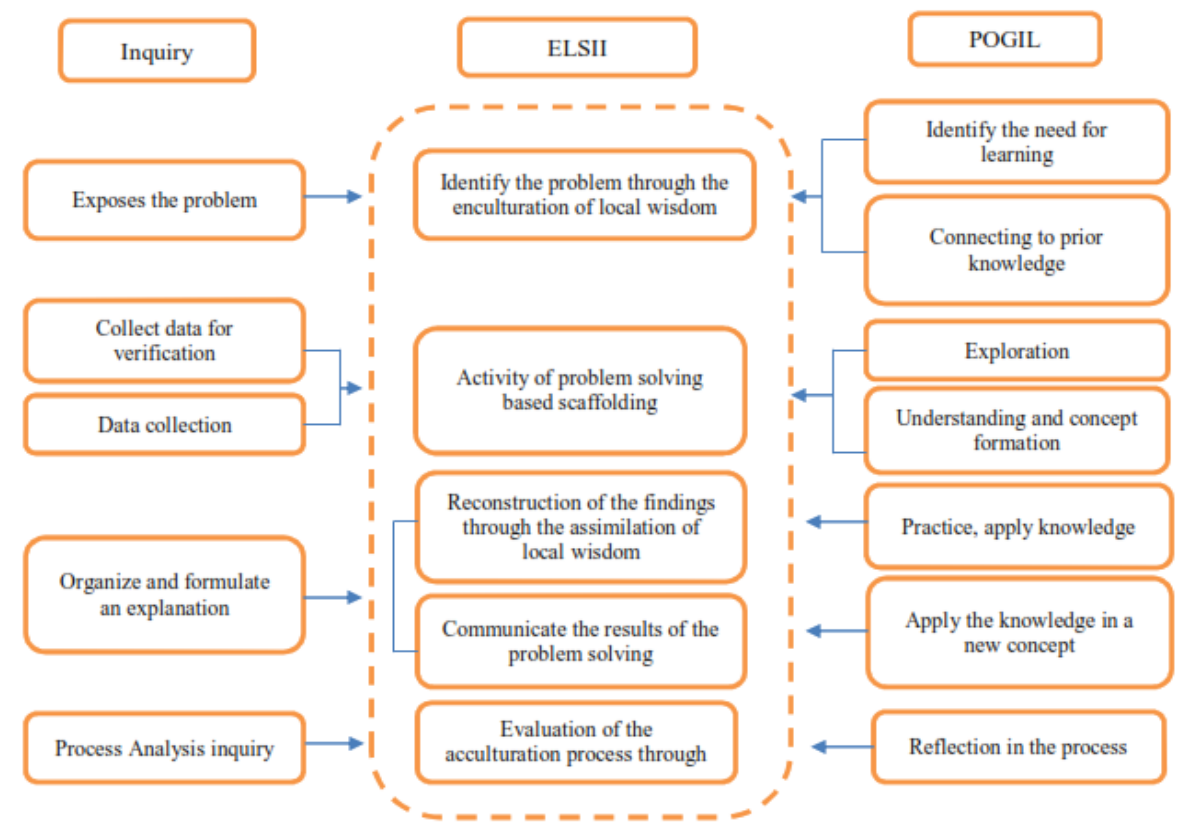

Figure 1

The Syntax of Local Wisdom-Based ELSII Learning Model

\section{Data Analysis}

The quantitative data were analyzed using non-parametric statistical test as the number of participants was less than 30 (Green \& Salkind, 2009). Statistic descriptive analysis was also administered to identify the characteristics of the research samples including 
the mean, standard of deviation, minimum score and maximum score. Furthermore, Mann-Whitney $U$ test was done to measure the differences in students' scores for problem solving and communication skills between two groups. Spearman's rho correlational test was then carried out to find out the correlation between dependent variables at a significant level of 0.5. The data analysis was done using SPSS 17.0 program.

\section{FINDINGS}

Before intervention was given to determine the initial skills of both groups, pretest had been administered. The results of the pretest showed that the average score of problem solving skills in the control group was slightly low in all sub-skills. After treatment was given, students in experimental group scored higher than those from control group. These results indicated students in experimental group achieved higher scores than those in the control group after being taught using local wisdom-based ELSII learning model (Table 2).

Table 2

Descriptive Data of Preservice Islamic Teachers' Problem Solving Skills

\begin{tabular}{|c|c|c|c|c|c|c|c|c|c|c|c|}
\hline \multirow[t]{2}{*}{ Groups } & \multirow{2}{*}{$\begin{array}{l}\text { Descripti } \\
\text { ve } \\
\text { Statistics }\end{array}$} & \multicolumn{5}{|l|}{ Pretest } & \multicolumn{5}{|l|}{ Posttest } \\
\hline & & $\begin{array}{l}\text { Overall } \\
\text { PSS }\end{array}$ & $\begin{array}{l}\text { Understand } \\
\text { the Problem }\end{array}$ & $\begin{array}{l}\text { Devise } \\
\text { a Plan }\end{array}$ & $\begin{array}{l}\text { Carry } \\
\text { out the } \\
\text { Plan }\end{array}$ & $\begin{array}{l}\text { Look } \\
\text { Back }\end{array}$ & $\begin{array}{l}\text { Overall } \\
\text { PSS }\end{array}$ & $\begin{array}{l}\text { Understand } \\
\text { the } \\
\text { Problem }\end{array}$ & $\begin{array}{l}\text { Devise } \\
\text { a Plan }\end{array}$ & $\begin{array}{l}\text { Carry } \\
\text { out the } \\
\text { Plan }\end{array}$ & $\begin{array}{l}\text { Look } \\
\text { Back }\end{array}$ \\
\hline \multirow[t]{4}{*}{$\begin{array}{l}\text { Experimental } \\
\text { Group }\end{array}$} & Mean & 5.616 & 5.607 & 5.607 & 5.536 & 5.616 & 9.223 & 9.214 & 9.036 & 9.179 & $\begin{array}{l}9.46 \\
4\end{array}$ \\
\hline & SD & .327 & .629 & .685 & .508 & .460 & .453 & .917 & .961 & .945 & .744 \\
\hline & Min & 4.75 & 4.00 & 4.00 & 5.00 & 5.00 & 8.00 & 7.00 & 7.00 & 7.00 & 8.00 \\
\hline & Max & 6.25 & 7.00 & 7.00 & 6.00 & 6.00 & 10.00 & 10.00 & 10.00 & 10.00 & $\begin{array}{l}10.0 \\
0\end{array}$ \\
\hline Control & Mean & 5.392 & 5.321 & 5.464 & 5.429 & 5.357 & 5.901 & 5.821 & 5.928 & 5.892 & 567 \\
\hline \multirow[t]{3}{*}{ Group } & SD & .336 & .612 & .637 & .573 & .559 & .248 & .548 & .663 & .567 & .331 \\
\hline & Min & 4.50 & 4.00 & 4.00 & 4.00 & 4.00 & 5.50 & 5.00 & 4.00 & 5.00 & 5.00 \\
\hline & Max & 6.00 & 6.00 & 6.00 & 6.00 & 6.00 & 6.25 & 7.00 & 7.00 & 7.00 & 7.00 \\
\hline
\end{tabular}

Students in the control group obtained slightly higher scores in the communication skills pretest for all subskills. Meanwhile, the results of the posttest showed that the experimental group obtained higher average score than the control group students. It can be inferred that students in the experimental group improved their communication skills after the treatment (see Table 3 ).

Table 3

Descriptive Data of Preservice Islamic Teachers' Communication Skills

\begin{tabular}{llllllllll}
\hline Groups & $\begin{array}{l}\text { Descriptive } \\
\text { Statistics }\end{array}$ & Pretest & \multicolumn{1}{c}{ Posttest } \\
\cline { 3 - 10 } & & Overall & $\begin{array}{l}\text { Verbal } \\
\text { skills }\end{array}$ & $\begin{array}{l}\text { Written } \\
\text { skills }\end{array}$ & $\begin{array}{l}\text { Social } \\
\text { skills }\end{array}$ & $\begin{array}{l}\text { Overall } \\
\text { CS }\end{array}$ & $\begin{array}{l}\text { Verbal } \\
\text { skills }\end{array}$ & $\begin{array}{l}\text { Written } \\
\text { skills }\end{array}$ & $\begin{array}{l}\text { Social } \\
\text { skills }\end{array}$ \\
\hline Experimental & Mean & 4.607 & 4.678 & 4.392 & 4.750 & 9.143 & 9.214 & 9.036 & 9.178 \\
Group & SD & .328 & .475 & .786 & .441 & .500 & .917 & .961 & .945 \\
& Minimum & 4.00 & 4.00 & 3.00 & 4.00 & 7.67 & 7.00 & 7.00 & 7.00 \\
& Maximum & 5.00 & 5.00 & 5.00 & 5.00 & 10.00 & 10.00 & 10.00 & 10.00 \\
\hline Control & Mean & 4.738 & 4.678 & 4.821 & 4.714 & 5.881 & 5.821 & 5.927 & 5.893 \\
Group & SD & .277 & .546 & .475 & .534 & .329 & .548 & .662 & .567 \\
& Minimum & 4.00 & 3.00 & 3.00 & 3.00 & 5.33 & 5.00 & 4.00 & 5.00 \\
& Maximum & 5.00 & 5.00 & 5.00 & 5.00 & 6.33 & 7.00 & 7.00 & 7.00 \\
\hline
\end{tabular}

To analyze the significant differences in students' scores of problem solving skills in two groups, Mann-Whitney $U$ test was carried out. Generally, there is no significant 
difference found between the two groups $(U=293.000 ; p=.091)$, yet for the subskill "devise a plan", a significant difference is found between experimental and control groups $(p=.017)$ (see Table 4$)$.

Table 4

The Difference in Pretest Problem Solving Skills Score between Experimental and Control Groups

\begin{tabular}{lllllll}
\hline \multicolumn{1}{c}{ Sub-Skills } & Groups & $N$ & Mean Rank & $\begin{array}{l}\text { Sum of } \\
\text { Ranks }\end{array}$ & & Mann-Whitney $U$ test \\
\cline { 5 - 7 } Understand the & LWB-ELSII & 28 & 28.84 & 807.50 & 382.500 & .846 \\
Problem & Traditional & 28 & 28.16 & 788.50 & & .017 \\
\hline Devise a Plan & LWB-ELSII & 28 & 32.64 & 914.00 & 276.000 & .017 \\
& Traditional & 28 & 24.36 & 682.00 & & .939 \\
\hline Carry out the Plan & LWB-ELSII & 28 & 28.38 & 794.50 & 388.500 & .182 \\
& Traditional & 28 & 28.63 & 801.50 & & \\
\hline Look Back & LWB-ELSII & 28 & 30.57 & 856.00 & 334.000 & .091 \\
& Traditional & 28 & 26.43 & 740.00 & & \\
\hline Overal PSS & LWB-ELSII & 28 & 32.04 & 897.00 & 293.000 & \\
& Traditional & 28 & 24.96 & 699.00 & & \\
\hline
\end{tabular}

The result of Mann-Whitney $U$ test showed a significant difference between the experimental and control groups in written communication skill ( $p=.017)$. However, in general, there were no significant differences found between the two groups $(U=302.500, p=.122)$ (see Table 5).

Table 5

The Difference in Pretest Communication Skills Score between Experimental and Control Groups

\begin{tabular}{|c|c|c|c|c|c|c|}
\hline \multirow[t]{2}{*}{ Sub-Skills } & \multirow[t]{2}{*}{ Groups } & \multirow[t]{2}{*}{$N$} & \multirow[t]{2}{*}{ Mean Rank } & \multirow{2}{*}{$\begin{array}{l}\text { Sum of } \\
\text { Ranks }\end{array}$} & \multicolumn{2}{|c|}{ Mann-Whitney $U$ test } \\
\hline & & & & & $U$ & $p$ \\
\hline Verbal & LWB-ELSII & 28 & 28.84 & 807.50 & \multirow[t]{2}{*}{382.500} & \multirow[t]{2}{*}{.846} \\
\hline Communication & Traditional & 28 & 28.16 & 788.50 & & \\
\hline Written & LWB-ELSII & 28 & 32.64 & 914.00 & \multirow[t]{2}{*}{276.000} & \multirow[t]{2}{*}{.017} \\
\hline Communication & Traditional & 28 & 24.36 & 682.00 & & \\
\hline Social & LWB-ELSII & 28 & 28.38 & 794.50 & \multirow[t]{2}{*}{388.500} & \multirow[t]{2}{*}{.939} \\
\hline Communication & Traditional & 28 & 28.63 & 801.50 & & \\
\hline \multirow[t]{2}{*}{ Overal CS } & LWB-ELSII & 28 & 31.70 & 887.50 & \multirow[t]{2}{*}{302.500} & \multirow[t]{2}{*}{.122} \\
\hline & Traditional & 28 & 25.30 & 708.50 & & \\
\hline
\end{tabular}

In the end of the treatment, both groups were given posttest. Overall, significant differences were found between those groups $(U=.000, p=.000)$. Significant differences were also found in each subskill ( $p>.05$ ) (see Table 6). 
Table 6

The Difference in Posttest Problem Solving Skills Score between Experimental and Control Groups

\begin{tabular}{|c|c|c|c|c|c|c|}
\hline \multirow[t]{2}{*}{ Sub-Skills } & \multirow[t]{2}{*}{ Groups } & \multirow[t]{2}{*}{$N$} & \multirow[t]{2}{*}{ Mean Rank } & \multirow{2}{*}{$\begin{array}{l}\text { Sum of } \\
\text { Ranks }\end{array}$} & \multicolumn{2}{|c|}{ Mann-Whitney $U$ test } \\
\hline & & & & & $U$ & $p$ \\
\hline Understand the & LWB-ELSII & 28 & 42.46 & 1189.00 & 1.000 & .000 \\
\hline Problem & Traditional & 28 & 14.54 & 407.00 & & \\
\hline \multirow[t]{2}{*}{ Devise a Plan } & LWB-ELSII & 28 & 42.43 & 1188.00 & 2.000 & .000 \\
\hline & Traditional & 28 & 14.57 & 408.00 & & \\
\hline \multirow[t]{2}{*}{ Carry out the Plan } & LWB-ELSII & 28 & 42.45 & 1188.00 & 1.500 & .000 \\
\hline & Traditional & 28 & 14.55 & 408.00 & & \\
\hline \multirow[t]{2}{*}{ Look Back } & LWB-ELSII & 28 & 42.50 & 1190.00 & .000 & .000 \\
\hline & Traditional & 28 & 14.50 & 406.00 & & \\
\hline \multirow[t]{2}{*}{ Overall PSS } & LWB-ELSII & 28 & 42.50 & 1190.00 & .000 & .000 \\
\hline & Traditional & 28 & 14.50 & 406.00 & & \\
\hline
\end{tabular}

Similar results were also found in students' CS posttest scores between the experimental and control groups. Significant differences were found in all subskills of CS between those groups $(p=.000)$ (see Table 7).

Table 7

The Difference in Posttest Communication Skills Score between Experimental and Control Groups

\begin{tabular}{lllllll}
\hline \multicolumn{1}{c}{ Sub-Skills } & Groups & $N$ & Mean Rank & Sum of & \multicolumn{2}{c}{ Mann-Whitney $U$ test } \\
\cline { 6 - 7 } & & & & Ranks & $U$ & $p$ \\
\hline Verbal & LWB-ELSII & 28 & 42.46 & 1189.00 & 1.000 & .000 \\
Communication & Traditional & 28 & 14.54 & 407.00 & & .000 \\
\hline Written & LWB-ELSII & 28 & 42.43 & 1188.00 & 2.000 & .000 \\
Communication & Traditional & 28 & 14.57 & 408.00 & & .000 \\
\hline Social & LWB-ELSII & 28 & 42.45 & 1188.50 & 1.500 & \\
Communication & Traditional & 28 & 14.55 & 407.50 & & .000 \\
\hline Overall CS & LWB-ELSII & 28 & 42.50 & 1190.00 & .000 \\
& Traditional & 28 & 14.50 & 406.00 & & \\
\hline
\end{tabular}

Regarding the results of students' PSS and CS tests results, the researchers assumed that there was a meaningful correlation between those $21^{\text {st }}$ century skills. To measure the correlational strength between PSS and CS, Spearman correlation test was administered. The result showed problem solving skills share positive and significant correlation with communication skills $(r=.822 ; p=.000)$.

\section{DISCUSSION}

The first objective of this research was to investigate the differences in PSS and CS between preservice Islamic teachers taught using local wisdom-based ELSII learning model and using traditional method. The pretest scores obtained by those two groups did not show any significant difference, implying that both groups had relatively equal initial competence. After treatment was conducted, experimental group showed significant improvement in their PSS and CS scores. Therefore, it can be understood that the ELSII learning model gave significant effect on preservice Islamic teachers' problem solving and communication skills. The significant improvement might be affected by the 
local wisdom-based ELSII learning model that opens up the chances for students to construct their meaningful learning experiences (Dewi, Poedjiastuti \& Prahani, 2017). Meaningful learning occurs when students are actively engaged in constructing their own comprehension based on their prior experiences and their interaction with the environment and adapting themselves to nature (Kanhadilok \& Watts, 2013; Moreno, 2010).

The ELSII learning model also offers the integration of local wisdom that conforms with the social constructivism learning approach proposed by Vygotsky (1978). This learning theory is supported by the syntax of ELSII learning model that gives emphasis on the importance of social interaction between student-student and student-lecturer, from which students are able to construct their own comprehension. On the other side, students in control group failed to obtain significant improvement in their PSS and CS as they were taught using teacher-centered traditional learning method which made the students become passive learners (Wahyudiati, 2016, Irwanto, Rohaeti, \& Prodjosantoso, 2018). Furthermore, Goldstein and Bevins (2016) stated that traditional learning methods ignore the principles of constructivism learning, leading to less meaningful learning.

The ELSII learning model employed in this research integrated the local potentials through enculturation, assimilation and acculturation in its learning process. Enculturation refers to the process of learning the cultural values and norms by individuals. The process is reflected in the first phase of ELSII learning model; identifying the problem through the enculturation of local wisdom (Dewi, Poedjiastui, \& Prahani, 2017). In this research, one of local content that was integrated in the learning process included the teaching of cultural norms and values of Sasak tribe in Lombok called Sangkep (Alkusaeri, 2017). Sangkep is the social system applied in Sasak community in solving various problems with strong emphasis on tolerance, cooperation, diversity, and deliberation. The learning process applied in this research was created based on those local wisdom, including identification of the problem, problem solving based on scaffolding, reconstruction finding, communicating the results, and acculturation evaluation based on the values of Sangkep. Those learning steps conform with the theory of learning proposed by Vygotsky which emphasizes on the organization of classroom situation, implementation of various strategies to enhance interaction between students and teachers, and the enhancement of interaction with the environment (Slavin, 1994). The learning environment as mentioned by Vygotsky covers the social environment, including the local cultural objects. This social interaction is believed to provide students with learning experiences that will help them construct their comprehension in better way compared to the use of traditional teaching method.

The result of this research showed that students' problem solving skills significantly improved after they were taught using local wisdom-based ELSII learning model. Significantly, Parwati, Sudiarta, Mariawan and Widiana (2018) and Shabrina and Kuswanto (2018) also concluded that local-wisdom based learning strengthens students' problem solving skills. The improvement might occur as this learning model adapts the principles of inquiry learning and POGIL, methods which have been proven to 
effectively develop students' critical thinking skills and problem solving skills (Apedoe, Walker, \& Reeves, 2006). Previous research also showed that the inquiry and POGIL methods has been effective in enhancing students' problem solving skills (Duran \& Dokme, 2016; Irwanto, Saputro, Rohaeti, \& Prodjosantoso, 2018; Seyhan, 2015; Villagonzalo, 2014). Additionally, Kolawole (2015) claimed that local knowledge made it easier for students to adapt to local cultures, where language was seen as an important means of expressing their identity.

In the current research, local wisdom-based ELSII learning model is not only effective in improving students' problem solving skills, but also reinforcing their communication skills. Supportively, Kim, Feng, Wang and Jang (2018) and Su (2008) also revealed that culture influences students' communication skills. The ELSII learning model is adapted from constructivism approach that is strongly relevant with sociocultural learning theories. It facilitates students to construct their comprehension through communication or interaction with the environment (Moreno, 2010). It has been confirmed by Adler and Rodman (2006) that the interaction with the environment affects students' communication strategies. During the treatment in this research, students were trained to do cooperative work and perform verbal communication (i.e. classroom discussion) (Dewi, Poedjiastuti, \& Prahani, 2017). Mercer-Mapstone and Matthews (2015) also viewed communication skills as important and useful skills in the future. Besides being able to enhance students' communication skills, Yusuf and Adeoye (2012) also stated that this method gives students the chance to negotiate and interact with other parties through verbal and non-verbal communication process.

Even, in Indonesia, local wisdom-based learning promotes students' conservationist characters, science literacy, critical thinking, science process skills and scientific attitudes (Dwianto, Wilujeng, Prasetyo, \& Suryadama, 2017; Khusniati, Parmin, \& Sudarmin, 2017; Setiawan, Innatesari, Sabtiawan, \& Sudarmin, 2017; Suardana, Redhana, Sudiatmika \& Selamat, 2018). This finding is also supported by Sochima (2013) who has successfully confirmed that the integration of cultural products in learning materials positively affects the improvement of students' cognitive and generic skills.

The second objective of this research was to investigate the correlation between PSS and CS among students in the experimental group. The results have confirmed the existence of strong and positive correlation between PSS and CS. This indicates that students' communication skills improve as they improve their problem solving skills. This view goes in line with the results of research conducted by Erozkan (2013) and Arslan (2010). Therefore, it is clear that sudents will be able to find the most appropirate solution to their problems when they have strong CS. It has been revealed in this resaerch that individuals with strong PSS and CS have better self-esteem reflected in how they give interpersonal responses (D'zurilla \& Nezu, 1990). Regarding to those facts, the implementation of local wisdom-based ELSII learning model gives positive contributions to the development of those skills. In the learning process, students solve problems in a collaborative way, in which they perform cooperative work and communication with their group members. This view is also supported by the results of 
previous research which also confirm that collaborative learning enhances students' critical thinking, communication and problem solving skills (Erozkan, 2013; Irwanto, Rohaeti, \& Prodjosantoso, 2018; Styron, 2014). Regarding to the findings of the current research, it is recommended that lectures apply collaborative and innovative learning models to develop students' $21^{\text {st }}$ century skills which will be very beneficial for students in facing the global challenges in the future.

\section{CONCLUSION AND SUGGESTIONS}

Based on the results, experimental group (taught using local wisdom-based ELSII) obtained significantly better problem solving and communication skills compared to the control group (taught using traditional method). After the treatment, students in experimental group showed significant improvement in all subskills of PSS and CS $(p>.05)$. A strong positive and significant correlation was also found between problem solving and communication skills $(r=.822 ; p=.000)$. It can be inferred from those results that improvement in problem solving skills is associated with the improvement in students' CS. Hence, local wisdom-based ELSII learning model can be considered an effective method to enhance students' $21^{\text {st }}$ century skills, especially problem solving and communication skills.

This research suffered from several limitations due to the small number of samples involved in this research and relatively short time in conducting the experiment (three months). Ideally, a good research takes one semester to finish in order to obtain more comprehensive results and to allow students to explore the materials more intensively. The results of this research provide alternatives for lecturers, researchers and curriculum developers to implement local wisdom-based ELSII learning model in their teaching practices. However, several characteristics should be assessed prior to the use of this method including students' characteristics, learning materials, and environmental conditions that should support team work and facilitate effective communication and interaction. It is expected that the optimization of collaborative and inquiry learning will give positive effects to the improvement of the $21^{\text {st }}$ century skills among students. More importantly, future researchers are encouraged to expand this research by investigating the effect of local wisdom-based ELSII learning model on students' cognitive achievement and other types of $21^{\text {st }}$ century skills. It is also suggested that future researchers involve higher number of participants, longer time to conduct the research and implement the model in ICT-based learning environment.

\section{REFERENCES}

Adler, R., \& Rodman, G. (2006). Understanding human communication. New York: Oxford University Press.

Alkusaeri. (2017). Pengembangan model pembelajaran matematika berbasis budaya Sasak [The development of cultural-based mathematic teaching method based on Sasak culture] (Unpublished doctoral dissertation). Universitas Negeri Yogyakarta, Yogyakarta. 
Apedoe, X. S., Walker, S. E., \& Reeves, T. C. (2006). Integrating inquiry-based learning into undergraduate geology. Journal of Geoscience Education, 54(3), 414-421. Arends, R. (2012). Learning to teach. New York: McGraw-Hill.

Arslan, E. (2010). Analysis of communication skill and interpersonal problem solving in preschool trainees. Social Behavior and Personality, 38(4), 523-530

Asmani, J. M. (2012). Buku panduan internalisasi pendidikan karakter di sekolah [Guidebook to the internalization of character building at schools]. Yogyakarta: Diva Press.

Asrori, A. (2015). Islamic education development strategy in facing the global challenges. International Journal of Science and Research, 11(4), 587-592.

Aydogdu, M, Guven, E., \& Aka, I. E. (2012). Effect of problem solving method on science method on science process skills and academic achievement. Journal of Turkish Science Education, 7(4), 13-25.

Aziz, Y. (2011). Penguatan mata kuliah pendidikan agama Islam di perguruan tinggi umum [Reinforcement of Islamic education subject in public universities]. Jurnal Sosial Humaniora, 4(2), 145-163.

Bailey, K. M. (2005). Practical English language teaching: Speaking. New York: McGraw-Hill.

Beyazsacli, M. (2016). Relationship between problem solving skills and academic achievement. The Anthropologist, 25(3), 288-293.

Çaliskan, S., Selçuk, G. S., \& Erol, M. (2010). Instruction of problem solving strategies: Effects on physics achievement and self-efficacy beliefs. Journal of Baltic Science Education, 9(1), 20-34.

Creswell, J. W. (2009). Research design: Qualitative, quantitative, and mixed methods approaches. Thousand Oaks, CA: Sage.

Cross, D., \& Smalldridge, A. (2011). Improving written and verbal communication skills for international medical graduates: A linguistic and medical approach. Medical Teacher, 33(7), 364-367.

Dewi, I. N., Poedjiastuti. S., \& Prahani, B, K. (2017). ELSII Learning model based local wisdom to improve students problem solving skills and scientific communication. International Journal of Education and Research, 5(1), 107-118.

Duran, M. (2014). A study on 7 grade student inquiry and communication competencies. Procedia-Social and Behavioral Sciences, 116, 4511-4516.

Duran, M., \& Dökme, I. (2016). The effect of the inquiry-based learning approach onstudent's critical-thinking skills. Eurasia Journal of Mathematics, Science and Technology Education, 12(12), 2887-2908. 
D’Zurilla, T. J., \& Chang, E. C. (1995). The relations between social problem solving and coping. Cognitive Therapy and Research, 19(5), 547-562.

D’Zurilla, T. J., \& Nezu, A. M. (1990). Development and preliminary evaluation of the social problem-solving inventory. Psychological Assessment: A Journal of Consulting and Clinical Psychology, 2(2), 156-163.

D’Zurilla, T. J., \& Nezu, A. M. (2007). Problem-solving therapy: A positive approach to clinical intervention. New York: Springer.

Dwianto, A., Wilujeng, I., Prasetyo, Z. K., \& Suryadarma, I G. P. (2017). The development of science domain based learning tool which is integrated with local wisdom to improve science process skill and scientific attitude. Jurnal Pendidikan IPA Indonesia, 6(1), 23-31.

Erozkan, A. (2003). The effect of communication skills and interpersonal problem solving skills on social self efficacy. Educational sciences Theory \& Practice, 13(2), 739-745.

Goffin, S. G., \& Tull, C. Q. (1985). Problem solving: Encouraging active learning. Young Children, 40(3), 28-32.

Goldstein, O., \& Bevins, S. (2016). A project-based learning approach to teaching physics for pre-service elementary school teacher education students. Cogent Education, $3(1), 1-12$.

Green, S. B., \& Salkind, N. J. (2008). Using SPSS for windows and Macintosh (Analyzing and understanding data). New Jersey: Pearson Prentice Hall.

Hair, F. J., Black, C. W., Babin, J. B., \& Anderson, E. R. (2010). Multivariate data analysis. New Jersey: Pearson Prentice Hall.

Ihmeideh, F. M., Al-Omari, A. A., \& Al-Dababneh, K. A. (2010). Attitudes toward communication skills among students'-teachers' in Jordanian public universities. Australian Journal of Teacher Education, 35(4), 1-11.

Iksan, Z. H., Zakaria, E., Meerah, T. S. M., Osman, K., Lian, D. K. C., Majmud, S. N. D., \& Krish, P. (2011). Communication skills among university students. Procedia Social and Behavioral Sciences, 59, 71-76.

Irwanto, Saputro, A. D., Rohaeti, E., \& Prodjosantoso, A. K. (2018). Promoting critical thinking and problem solving skills of preservice teachers through process-orientedguided-inquiry learning (POGIL). International Journal of Instruction, 11(4), 777-794.

Irwanto, Saputro, A.D., Rohaeti, E., \& Prodjosantoso, A.K. (2019). Using inquiry-based laboratory instruction to improve critical thinking and scientific process skills among preservice elementary teachers. Eurasian Journal of Educational Research, 80, 151170. 
Irwanto, Rohaeti, E., \& Prodjosantoso, A. K. (2018). Undergraduate students' science process skills in terms of some variables: A perspective from Indonesia. Journal of Baltic Science Education, 17(5), 751-772.

Ismiani, S., Syukri., \& Wahyudiati, D. (2017). Pengaruh penerapan metode problem based learning terhadap sikap ilmiah dan hasil belajar biologi siswa kelas vii Mts nw01 Kembang Kerang [The effect of problem-based learning on the scientific attitude and learning outcome of biology subject among 7th graders in Mts nw01 Kembang Kerang]. Biota, 10(1), 68-75.

Kanhadilok, P., \& Watts, M. (2013). Western science and local Thai wisdom: Using museum toys to develop bi-gnosis. Canadian Journal of Science, Mathematics and Technology Education, 13(1), 33-48.

Kayi, H. (2006). Teaching speaking activities to promote speaking in a second language. The Internet TESL Journal, 12(11), 33-49.

Khachatryan, D., \& Karst, N. (2017). V for voice: Strategies for bolstering communication skills in statistics. Journal of Statistics Education, 25(2), 68-78.

Khusniati, M., Parmin, \& Sudarmin. (2017). Local wisdom-based science learning model through reconstruction of indigenous science to improve student's conservationist character. Journal of Turkish Science Education, 14(3), 16-23.

Kim, I., Feng, B., Wang, B., \& Jang, J. Y. (2018). Examining cultural and gender similarities and differences in college students' value of communication skills in romantic relationships. Chinese Journal of Communication, 11(4), 1-18.

Kolawole, O. D. (2015). Twenty reasons why local knowledge will remain relevant to development. Development in Practice, 25(8), 1189-1195.

Lonto, A. L. (2015). Pengembangan model pendidikan karakter berbasis nilai sosiokultural pada siswa SMA di Minahasa [The development of character building method based on socio-cultural values for high school students in Minahasa]. Jurnal Sosial dan Pembangunan, 31(2), 319-327.

Mercer-Mapstone, L. D., \& Matthews, K. E. (2015). Student perceptions of communication skills in undergraduate science at an Australian research-intensive university. Assessment \& Evaluation in Higher Education, 42(1), 98-114.

Moreno, R. (2010). Educational psychology. Hoboken, N.J.: John Wiley \& Sons.

Parwati, N. N., Sudiarta, I. G. P., Mariawan, I. M., \& Widiana, I. W. (2018). Local wisdom-oriented problem-solving learning model to improve mathematical problemsolving ability. Journal of Technology and Science Education, 8(4), 310-320.

Penbek, S., Şahin, D, Y., \& Cerit, A. G. (2012). Intercultural communication competence: A study about the intercultural sensitivity of university students based on their education and international experiences. International Journal of Logistics Systems and Management, 11(2), 232-252. 
Polya, G. (1957). How to solve it. Princeton: Princeton University Press.

Sadia, W. (2013). Model pendidikan karakter terintegrasi pembelajaran sains [The integration of character building in science education]. Jurnal Pendidikan Indonesia, 2(2), 209-220.

Sanabria, J. C., \& Jesús, A.-L. (2017). Enhancing 21st century skills with AR: Using the gradual immersion method to develop collaborative creativity. Eurasia Journal of Mathematics, Science and Technology Education, 13(2), 487-501.

Santrock, J. W. (2011). Educational psychology. New York: McGraw Hill.

Setiawan, B., Innatesari, D. K., Sabtiawan, W. B., \& Sudarmin. (2017). The development of local wisdom-based natural science module to improve science literation of students. Jurnal Pendidikan IPA Indonesia, 6(1), 49-54.

Seyhan, H. G. (2015). The effects of problem solving applications on the development of science process skills, logical thinking skills and perception on problem solving ability in the science laboratory. Asia-Pacific Forum on Science Learning and Teaching, 16(2), [8].

Shabrina, \& Kuswanto, H. (2018). Android-assisted mobile physics learning through Indonesian batik culture: Improving students' creative thinking and problem solving. International Journal of Instruction, 11(4), 287-302.

Shih, Y. L., \& Singh, C. (2013). Using an isomorphic problem pair to learn introductory physics: Transferring from a two-step problem to a three-step problem. Physical Review Special Topics-Physics Education Research, 9(2), 1-21.

Slavin, R. (1994). Educational psychology, theory and practice. Massachusetts: Allyn \& Bacon Publisher.

Sochima, S., \& Unodiaku. (2013). Effect of ethno-mathematics teaching materials on students' achievement in mathematics in Enugu state. Journal of Education and Practice, 4(23), 70-77.

Styron, R. A. (2014). Critical thinking and collaboration: A strategy to enhance student learning. Systemic, Cybernetics and Informatics, 12(7), 25-30.

Su, K.-D. (2016). Strengthening strategic applications of problem-solving skills for Taiwan students' chemistry understanding. Journal of Baltic Science Education, 15(6), 662-679.

Su, Y.-C. (2008). Promoting cross-cultural awareness and understanding: incorporating ethnographic interviews in college EFL classes in Taiwan. Educational Studies, 34(4), 377-398.

Suardana, I. N., Redhana, I. W., Sudiatmika, A. A. I., \& Selamat, I. N. (2018). Students' critical thinking skills in chemistry learning using local culture-based 7e learning cycle model. International Journal of Instruction, 11(2), 399-412. 
Suyitno, I. (2012) Pengembangan pendidikan karakter dan budaya bangsa berwawasan kearifan lokal [The development of character building and local wisdom-based cultural content]. Jurnal Pendidikan Karakter, 2(1), 1-13.

Tatar, N. (2006). The effect of inquiry-based learning approaches in the education of science in primary school on the science process skills, academic achievement and attitude (Unpublished doctoral dissertation). Gazi University, Turkey.

Temel, V. (2015). The problem-solving skills of the teachers in various branches. Educational Research and Reviews, 10(5), 641-647.

The Partnership for 21st Century Skills [P21]. (2002). Learning for the 21st century: A report and mile guide for 21st century skills. Retrieved from http://www.p21.org/storage/documents/P21_Report.pdf.

The Partnership for 21st Century Skills [P21]. (2019). Framework for 21st century learning. Retrieved from http://www.battelleforkids.org/networks/p21/frameworksresources.

Trilling, B., \& Fadel, C. (2009). $21^{\text {st }}$ century learning skills. San Francisco, CA: John Wiley \& Sons.

Villagonzalo, E, C. (2014). Process oriented guided inquiry learning: an effective approach in enhancing students' academic performance. Presented at the DLSU Research Congress, De La Salle University, Manila, Philippines.

Vygotsky, L. S. (1978). Mind in society. Cambridge: Harvard University Press.

Wagiran. (2011). Pengembangan model pendidikan kearifan lokal dalam mendukung visi pembangunan provinsi Daerah Istimewa Yogyakarta [The Development of local wisdom-based education in supporting the visions of regional development in special region of Yogyakarta]. Jurnal Penelitian dan Pengembangan, 3(3), 85-100.

Wahyudiati, D. (2016). Analisis efektivitas kegiatan praktikum sebagai upaya peningkatan hasil belajar mahasiswa [Analysis on the effectiveness of practicum activities in improving students' learning outcome]. Tastqif, 14(2), 143-168.

Yusuf, F. A., \& Adeoye, E. A. (2012). Developing critical thinking and communication skills in students skills in student: Implications for practice in education. African Research Review, 6(1), 311-324.

Zeidan, H. A., \& Jayosi, R. M. (2014). Science process skills and attitudes toward science among Palestinian secondary school students. World Journal of Education, 1(5), $13-24$. 